\title{
Fizik Öğretiminde Deneyler: Laboratuvar Becerilerinin Gelişimine İlişkin Bir Yaklaşım \\ Olga GKIOKA
}

\author{
Boğaziçi Üniversitesi, 34342 Bebek, İstanbul, Türkiye \\ olga.gkioka@boun.edu.tr, http://orcid.org/0000-0002-0477-3217
}

Gönderme Tarihi : 03.05.2019

Kabul Tarihi : 06.04.2020

Doi: $10.17522 /$ balikesirnef.560416

\begin{abstract}
Özet - Bu makale, fizik öğretiminde deneylerin, laboratuvar becerilerini geliştirdiği fikrini desteklemek amacıyla yapılan bir çalışmadır. Makale, Avrupa ve ABD'deki farklı müfredatlarda laboratuvar çalışmalarının rolünü tartışarak, laboratuvar çalışmalarının laboratuvar becerilerinin geliştirilmesine sağladığ 1 katkılara yönelik müfredat dökümanlarına vurgu yapmaktadır. Ardından 123 fizik öğretmen adayı ile yapılan deneysel çalışmanın bulguları rapor edilmektedir. Çalışma, eğitim fakültesi fizik öğretmenliği bölümünde öğrenim gören öğretmen adaylarının eğitim programı kapsamında gerçekleştirilmiştir. Katılımcılar üç yıl süresince altı farklı yarıyılda gruplandırılmıştır. Süreç boyunca katılımcılar deney yapma, laboratuvar raporu hazırlama ve okul ortamlarında laboratuvar kullanımını öğretmek amacıyla ders planları hazırlama gibi eylemleri gerçekleştirmiş̧lerdir. Ayrıca, ders planlarının hazırlık sürecinde birçok katılımcı ile kısa görüşmeler yapılmıştır. Araştırmanın temel amacı, öğretmen adaylarının fizik öğretiminde deneylerin amaçlarını kavramalarını sağlamak ve laboratuvar uygulamaları için ders planı hazırlarken karşılaştıkları zorlukları tespit etmektir. Program genel olarak, katılımcıların "deneyler, bir hipotezi kanıtlamak veya bir teoriyi doğrulamak için kullanıllı" fikrinden "deneyler, hedeflediğimiz laboratuvar becerilerinin geliştirilmesini sağlar" fikrine doğru kademeli bir değişimi sağlamasında başarılı olmuştur. Son olarak ise, Türkiye'deki müfredat geliştirme ve öğretmen eğitimi üzerine uygulamalar tartışılmıştır.
\end{abstract}

Anahtar Kelimeler: laboratuvar becerileri, laboratuvar çalışması, fizik öğretiminde deneyler, fizik müfredatı, fizik öğretmeni eğitimi.

Sorumlu Yazar: Olga GKIOKA, Boğaziçi Üniversitesi, Fizik Öğretmenliği Bölümü, olga.gkioka@ boun.edu.tr

\section{Geniş Özet}

$\mathrm{Bu}$ çalışmada, fizik öğretiminde deneylerin, laboratuvar becerilerini geliştirdiği fikrini desteklemek amacıyla yapılan bir araştırmanın bulguları rapor edilmektir. Çalışma, Avrupa ve ABD’deki farklı müfredatlarda laboratuvar çalışmalarının rolünü tartışarak, laboratuvar çalışmalarının laboratuvar becerilerinin geliştirilmesine sağladığı katkılara yönelik müfredat dökümanlarına vurgu yapmaktadır.

Fizik öğretmenliği hazırlık programlarının içerik bilgisi ve teoriye odaklanması çok sık görülen bir durumdur. Fizik öğretmen adayları, eğitim süreçleri boyunca ortaöğretim öğrencilerinin fizik dersinde belirli alanlardaki kavram yanılgıları ve öğrenmede zorluk 
yaşadıkları konular (ör. Hareket, dinamik, elektrik vb.) hakkında bilgi edinirler. Fakat fizik sadece teori, kavramlar, yasalar ve formüllerden ibaret değildir. Fizik aynı zamanda deneysel bir bilim dalıdır. Laboratuvar çalışmaları da fiziğin merkezinde yer almaktadır.

Türkiye'de laboratuvar çalışmaları okul fen/fizik müfredatlarının ihmal edilen bir parçasıdır. Ortaöğretim Fizik Müfredatı (TTB, 2018) deneyleri içermesine rağmen, genellikle fizik derslerinin olağan öğretim süreçlerine deneyler sıklıkla dahil edilmemektedir.

“Hedef” terimi, öğretmenin belirli bir sınıf ve belirli bir ders dilimi zamanı için karar verilen hedeflerini belirtmek için kullanılmıştır. Öğretmen niçin deney kullanır? Öğretmen belirli bir deney yaparak öğrencilerinin ne öğrenmesini ister? Öğretmen, öğrencilerinin hangi kavramsal bilgileri veya laboratuvar becerilerini geliştirmelerini ister?

"Amaç" ise "hedef”ten farklıdır. "Amaç", laboratuvar faaliyetlerinin sonuçlarını, genellikle bilimsel teori ve bilgi açısından ifade eder. "Amaç”, laboratuvar raporlarının başında yazılması gereken ifadedir. Deney yapan kişinin saptayacağı ya da keşfedeceği şey nedir?

Örneğin; serbest düşme deneyinin "amacı”, ivmelenme sabitinin (g) değerini belirlemek olabilir. Ancak, "hedef” öğretim hedefleri ile ilgilidir; lise öğrencilerine bir deneyi nasıl planlayacağını, değişkenleri nasıl belirleyeceğini, grafikleme ve analiz yapma becerilerini nasıl geliştirebileceğini öğretmek gibi. Böylece öğretmen, öğretim sıralamasında deneyin neden ve ne zaman geldiğine ve deneyin diğer öğrenme deneyimleri ve daha önce geliştirilmiş olan laboratuvar becerileriyle nasıl ilişkilendirileceğine karar verir.

Amerikan Fizik Öğretmenleri Birliği’nin (AAPT) Raporlarına (1997; 2014) göre, lisans düzeyi fizik laboratuvarı için belirtilen "amaç" öğrencilerin deneyler yoluyla laboratuvar becerilerini geliştirmesidir. Eşsiz bir öğrenme ortamı olan fen laboratuvarı, "Her öğrenciyi, araştırma tasarlamadaki bazı amaçlar da dahil olmak üzere, deneysel süreçlerle birlikte önemli deneyimlerle meşgul etmesi gereken bir ortamdır. Laboratuvar, öğrencilerin geniş kapsamlı temel beceri ve deneysel fizik ve veri analizi araçları geliştirmesine yardımcı olmalıdır." (AAPT, 1994, p 546). Sunulan çalışma AAPT'nın bu yaklaşımını benimsemiştir.

\section{Yöntem}

Yüz yirmi üç (123) öğretmen adayı ile yapılan deneysel bir araştırma çalışması gerçekleştirilmiştir. Çalışma, Fizik Öğretmenliği Bölümünde öğrenim gören öğretmen adaylarının eğitim programı kapsamında gerçekleştirilmiştir. Katılımcılar üç yıl süresince altı farklı yarıyılda gruplandırılmıştır. Süreç boyunca katılımcılar deney yapma, laboratuvar raporu 
yazma ve okul laboratuvarında öğretmek üzere ders planı hazırlama gibi eylemleri gerçekleştirmişlerdir. Ayrıca, ders planları hazırlama sürecinde birçok katılımcı ile görüşmeler de gerçekleştirilmiştir. Araştırmanın amacı, öğretmen adaylarının fizik öğretiminde deneylerin amaçlarını kavramalarını sağlamak ve laboratuvar uygulamaları için ders planı hazırlarken karşılaştıkları zorlukları tespit etmektir.

$\mathrm{Bu}$ araştırmayı yönlendiren araştırma soruları şunlardır:

(1) Öğretmen adaylarının deneylerin amacını anlayış biçimleri nelerdir?

(2) Öğretmen adaylarının fizik öğretimindeki deneylerin hedefini anlayış biçimleri nelerdir?

(3) Öğretmen adayları okul fizik laboratuvarında kullanmak üzere ders planı hazırlarken ne tür zorluklarla karşılaşırlar?

\section{Bulgular}

Sonuçlarda, ders planları örneklerine ve geliştirilen öğretim materyallerine, yapılan görüşmelere ve laboratuvar raporlarından yapılan alıntılara yer verilmiştir. Çalışmanın sonuçları aşağıdaki üç ana alt başlık altında sunulmuştur:

(1) Öğretmen adaylarının deneylerin amacını kavrayışları,

(2) Öğretmen adaylarının deneylerin hedeflerini kavrayışları ve

(3) Öğretmen adaylarının ders öğretimi için hazırlık ve planlamada yaşadıkları zorluklar.

Program, katılımcıların "deneyler, bir hipotezi kanıtlamak veya bir teoriyi doğrulamak için kullanılır” fikrinden “deneyler, hedeflediğimiz laboratuvar becerilerinin geliştirilmesini sağlar” fikrine doğru kademeli bir değişimi sağlamada başarılı olmuştur.

Öğretmen adayları için laboratuvarda ders vermeye hazırlanmak büyük bir zorluktur. Belirli deneysel becerilerin gelişimi ile ilgili öğrenme hedefleri doğrultusunda ders planı hazırlama oldukça zorlayıcı olmuştur. Öğretmen adaylarının laboratuvar becerilerini öğretmek konusunda kendilerinden emin olmadıkları ve ders planlarının niteliklerinin zayıf olduğu görülmüştür.

Öğrencilerin, öğrenme kazanımlarını yazmada ve laboratuvar becerilerinin geliştirilmesi ile ilgili amaçların öğretilmesinde zorluk yaşadıkları görülmüştür. Tüm yaşadıkları bu zorlukların, kendi öğrencilik deneyimleri sırasında tüm fizik eğitimi sınıflarında, 
ders planları geliştirmek adına sadece fizik kavramlarını (teori) öğretmek için eğitim almış ve bunun üzerine pratik yapmış olmalarından kaynaklandığı düşünülmektedir.

\section{Tartışma ve Öneriler}

Çalışmada öğretmen adaylarının deneylerin amaçlarını kavrayış biçimleri, deney hedeflerini kavrayışları ve ders planı ve ders öğretimi hazırlığında karşılaştıkları zorluklar incelenmiştir. Çalışma kapsamında uygulamaya dayalı çalışmaların öğrencilerin geniş bir yelpazede laboratuvar becerilerini geliştirmelerine yardımcı olması gerektiği fikri benimsenmiştir. Diğer bir deyişle pratik uygulamalar öğrencilerin deney planlama, veri grafikleme, verileri analiz edebilme ve değişkenler arasındaki ilişkiyi tanımlayabilme gibi becerilerinin gelişimini desteklemelidir. Yapılan çalışma ile bu alanda önceki çalışmaların sonuçları doğrulanarak, aynı zamanda yeni bulgular da ortaya çıkarılmıştır.

Son olarak, Türkiye'deki müfredat geliştirme ve öğretmen adaylarının eğitimi üzerine uygulamalar tartışılmıştır. $\mathrm{Bu}$ araştırma bulguları, fizik öğretmenlerinin yetiştirilmesi için derslerin geliştirilmesi ihtiyacına güçlü destek sunmaktadır. Fizik öğretmen adayları, uygulamalı laboratuvar becerileri öğretimi üzerine daha fazla öğrenme deneyimlerine ihtiyaç duymaktadırlar. Öğretmen adaylarına daha fazla laboratuvar ders planları hazırlama ve öğretim materyalleri geliştirmelerine imkân sağlayacak dersler sunulmalıdır. 


\title{
Experiments in Physics Teaching: Towards an Approach to Laboratory Skills Development Olga GKIOKA
}

\author{
Boğaziçi University, 34342 Bebek, Istanbul, Turkey \\ olga.gkioka@boun.edu.tr, http://orcid.org/0000-0002-0477-3217 \\ Received : 03.05.2019 \\ Accepted : 06.04.2020
}

Doi: 10.17522/balikesirnef.560416

\begin{abstract}
The aim of the present paper is to report on a research study which aimed to promote the idea that experiments in physics teaching should enhance the development of laboratory skills. The paper begins with a discussion of the role of laboratory work, as presented in different curricula in Europe and the US. Emphasis has been given to curriculum guidelines, according to which, laboratory work should promote the development of laboratory skills. Then, an empirical research study with one hundred and twenty-three (123) pre-service physics teachers has been reported. The study took place within the context of a pre-service teacher education program in a Department of Physics Teaching. The participants were distributed in six different semesters during three years. They performed experiments, wrote laboratory reports and prepared lesson plans to teach in the school laboratory. In addition, short interviews were conducted with quite many of them, while preparing lesson plans. The research goal was to investigate teachers' understanding of the purpose of experiments in physics teaching and their difficulties when preparing lesson plans to teach in the lab. The program was successful in helping the participants to gradually 'shift' from the idea that experiments are used to verify a hypothesis or confirm theory, to the position that experiments should promote the development of laboratory skills. Implications for curriculum development and pre-service teacher education in Turkey have been discussed.
\end{abstract}

Keywords: experiments in physics teaching, laboratory skills, laboratory work, physics curriculum, physics teacher education.

Corresponding author: Olga GKIOKA, Boğaziçi University, Department of Physics Teaching,

olga.gkioka@boun.edu.tr 


\section{Introduction}

It is most often that physics teacher preparation emphasizes content knowledge and theory. Pre-service physics teachers learn about secondary students' misconceptions and difficulties in specific areas of physics (i.e., motion, dynamics, electricity and so on). But, physics is not only theory, concepts, laws and formulas. It is also an experimental science. Laboratory work is at the heart of physics.

In Turkey, laboratory work is a neglected part of the school science curriculum. Although the National Science Curriculum (Talim Terbiye Kurulu Baskanlığı, 2018) includes experiments, it is often, that physics classes do not include experimentation in usual teaching. It may be that requirements for high-stake exams restrict teachers' instruction and time available to teach laboratory work. In addition, in pre-service teacher education, major emphasis is given to the conceptual understanding of physics and concepts across the curriculum. Pre-service physics teachers prepare lesson plans, do micro-teaching in the Faculty of Education and practice teaching mainly concepts of physics in internship schools. Although we give much importance on concept learning and conceptual development of pre-service teachers' subject content knowledge, this is not the case with laboratory work.

Throughout the paper, the term of "practical work", which is common in the UK and German context, and "laboratory work", common in the US, have been used interchangeably. With the term of "practical work" or "laboratory work", we generally refer to experiences in school settings in which students interact with equipment and materials or secondary sources of data to observe and understand the natural world (Hegarty-Hazel, 1990).

In addition, we use the word "students" to refer to secondary school students. On the other hand, "pre-service physics teachers" or "teachers" refer to undergraduate physics teachers or pre-service teachers who are supposed to teach after a few years in secondary schools.

The "purpose" has been used to refer to teacher's intentions, which have been decided for the experiment in a particular class and at a particular time within a unit of lessons. Why does the teacher use an experiment? What does the teacher want her/his students to learn by performing a particular experiment? What conceptual knowledge or laboratory skills does the teacher want his/her students to develop?

The "purpose" is different from the "aim" of the experiment. The "aim" of the experiment refers to the outcomes of the lab activity, usually in terms of scientific theory and 
knowledge. It is the statement that should be written at the beginning of the lab report. What is it that the experimenter is going to determine or find out?

For example, the "aim" of the free fall experiment may be to determine the value of constant of acceleration (g). But the "purpose" is related to the teaching goals; to teach how to plan the experiment, identify the variables, develop graphing skills or to develop analysis skills in secondary school students. The teacher should then, decide on why and when the experiment comes in the teaching sequence, and how the experiment links with other learning experiences and previously developed laboratory skills.

\section{What is the value of laboratory work in physics instruction?}

Laboratory work has had a distinctive role in science teaching and learning as determined by science curricula across various countries. According to Lazarowitz and Tamir (1994), the laboratory provides the only place in school where certain kinds of skills, abilities, and understandings can be developed. A wide range of benefits have been suggested that derive from secondary students' engagement in laboratory activities. Physics education through practical work may target diverse goals: (a) conceptual understanding; to teach and promote conceptual knowledge and understanding in students (Trumper, 2002; Bozzo, 2020), (b) to teach the nature of science (Hart, Mulhall, Berry, Loughran \& Gunstone, 2000), (c) development of processes of science and problem-solving abilities and, (d) enhancement of interest and motivation.

The various studies included in the reviews by Lazarowitz and Tamir (1994) and by Hofstein and Lunetta $(1982 ; 2004)$ revealed that teachers may conduct experiments without clear purposes and goals. Several research studies reported that students regularly perform school experiments with very different purposes in mind than those perceived by their teachers (Lunetta, Hofstein \& Clough, 2007). Furthermore, Lunetta and his team noted that classroombased studies reveal that such mismatches between teachers' goals, theory and learning outcomes limit the effectiveness of the laboratory in science teaching.

Hodson (1993) and Lunetta et al., (2007) argued that practical work alone is not sufficient to enable students to develop the complex conceptual understandings and theory. In fact, Lunetta et al., (2007) argued that laboratory work alone is not sufficient to enable students to develop the complicated conceptual understandings accepted by science. Gunstone (1991) wrote that helping students develop scientific concepts and theory from lab experiments is a very complex process. This is true, since the conceptual challenge or conflict, as derived from 
constructivism, is more complicated when it occurs in the laboratory. Also, Gunstone and Champagne (1990) suggested that meaningful learning in the laboratory would occur if students were given opportunities for interaction and reflection in order to initiate discussion. However, students generally do not have sufficient time and support to reflect on the data and on the main scientific concepts involved in the experiment. Gunstone and Champagne (1990) argued that laboratory work could successfully be used to promote conceptual change if small qualitative laboratory tasks are used.

Some studies identified several reasons for this unsatisfactory situation. For example, Tamir (1991) suggested as one possible reason, the fact that lessons are perceived by students as isolated events, and not as a part of related series of experiments. Or, that the teacher's purpose would be different from that of the students. This may be the case, as teachers quite often do not state the purpose or even when they do, they do not make sure that the students understand it (Tamir, 1991). Tobin (1990) suggested that meaningful learning is possible in the laboratory if students are given opportunities to manipulate equipment and materials so as to be able to construct their knowledge of phenomena and related scientific concepts. However, Tobin claimed that research studies on practical work have not provided evidence that such opportunities really exist.

A similar point was made by Schauble, Glaser, Duschl, Schulze and John (1995) whose research results revealed a discrepancy between students' and teachers' understanding of the purposes of experiments and the related reasoning. Etkina, Van Heuvelen, Brookes and Mills (2002) argued that traditional "cookbook" experiments in labs and lecture demonstrations achieve too little. This is because when students follow recipe-type laboratory or "cookbook" activities to verify or illustrate a concept or a principle, the purpose is to develop lower leveltype skills. The development of laboratory skills in students has been the goal of quite many laboratory courses developed by Wilcox and Lewandowski (2017), too.

More recently, in the United Kingdom (UK), Abrahams and Millar (2008; 2009) investigated the effectiveness of practical work by analyzing a sample of twenty-five (25) "typical" science lessons involving practical work in English secondary schools. They concluded that the teacher's focus in such lessons was predominantly on making students manipulate physical objects and equipment. Hardly any teachers focused on developing experimental skills in students.

Necatibey Eğitim Fakültesi Elektronik Fen ve Matematik Eğitimi Dergisi 
Hu, Zwickl, Wilcox and Lewandowski (2017) conducted a research study to investigate how university physics students viewed the role of physics experiments in physics courses. They found out that their views varied according to their laboratory experiences and the level of their study. Thus, introductory students view experiments as tools which are neccessary to enhance conceptual learning. This is in contrast with higher-level students up to the $\mathrm{PhD}$ level who believe that experiments offer unique opportunities to develop laboratory and professional skills. For the introductory undergraduate physics students, experiments are needed to verify or illustrate theory. More experienced undergraduate students believe in the value of experimentation towards the development of the understanding of evidence, of the quality of evidence and so on.

Along the same line, Holmes, Olsen, Thomas and Wieman (2017) have emphasized that institutions and departments should re-examine the goals and conduct of their lab courses. They have talked about goals and instructional approaches which can make lab courses more educationally valuable. Their research presented srong evidence that lab courses do not promote the development of scientific theory in students. Therefore, one of the main argument is to do with restructuring lab courses to better support the developmet of certain laboratory skills and scientific practices.

Khaparde (2019) has suggested an "experimental problem solving” approach developed for and implemented in the physics laboratory. In this approach, students are given "experimental problems" and they need to make decisions on several aspects and how to proceed. They perform self-guided experimental work with minimal help from the instructor. Thus, in such an approach, procedural understanding, experimental skills and problem solving abilities have been integrated.

\section{Emphasis on the development of laboratory skills}

According to the American Association of Physics Teachers' (AAPT) Reports (1997; 2014) for the undergraduate physics laboratory, the goal is, through the experiments, students to develop laboratory skills. The science laboratory, a unique learning environment, is a setting which "should engage each student in significant experiences with experimental processes, including some experience in designing investigations. The laboratory should help students develop a broad array of basic skills and tools of experimental physics and data analysis" (AAPT, 1994, p 546). The presented study has adopted the AAPT position. 
What do we mean by "laboratory skills"? Students should be able to design experiments, develop technical and practical skills, analyze and visualize data and communicate physics. When performing an experiment, students start with defining a question for investigation, they identify the variables, make a prediction, design the investigation, plan the experiment and perform it, collect measurements, plot the data and draw graphs, analyze the data, interpret the data by using theory, draw conclusions and finally, evaluate the results and the followed method.

The teacher should decide on the specific teaching goals, which means the particular laboratory skills that he intends to develop in his students. Then, the laboratory activities should give some freedom to students to decide on the aim of the experiment; that is, what it is that they want to determine or calculate and so on. For example, while they perform Hooke's law experiment, we do not want them to test theory or verify Hooke's law but, them to determine some quantities (i.e., constant of springs) based on the collected measurements.

The research questions guiding this study are the following:

(1)What are the pre-service physics teachers' understandings of the aim of experiments?

(2) What are the pre-service physics teachers' understandings of the purpose of experiments in physics teaching?

(3) What are the pre-service physics teachers' difficulties in preparing lesson plans to teach in the school phyics laboratory?

\section{Research Methodology}

\section{Context of the study and the participants}

The study took place within the context of a pre-service teacher education program in a Department of Physics Teaching during the 2015-2018 years. In our department, an initiative was taken to prepare our pre-service physics teachers to teach experiments in the school physics laboratory. The research study presented in this paper is a part of a bigger research project (Gkioka, 2019). During the course, the participants were introduced to research-based teaching methods in the laboratory. The course was specifically designed for pre-service physics teachers and was taught for five hours per week for thirteen (13) weeks a semester. The participants 
performed experiments, wrote laboratory reports and prepared lesson plans and teaching materials to teach in the school laboratory.

The experiments they performed were the usual school experiments (i.e., Hooke's law, Ohm's law, electromagnetic induction experiment, insulation, free fall and so on). They were mainly controlled experiments (or "fair" tests). The experiments were carried out so that the participants had the opportunity to design them by themselves without any guidelines. In contrast, when they were performing experiments in the physics department labs, they were given detailed instructions on how to write the report; they would mainly answer some questions. All of them had completed four undergraduate compulsory laboratory courses in the Physics Department. After each experiment, they wrote and submitted a lab report. Again, they prepared the report without guidelines.

The participants were one hundred and twenty-three (123) pre-service physics teachers, distributed in six different semesters during three years. Thus, the participants were the undergraduate students who registered for the course. No selection or changes were made to the students who registered for the course. Thus, such a study included convenience sampling.

The university is a public one with English as official language. Therefore, all tasks and lesson plans will be in English.

Samples of teaching materials were developed and delivered to teachers, including sequence of teaching goals. In addition, teachers were given opportunities to plan and develop their own teaching materials.

\section{Research Methods}

The study has employed qualitative research methods (Erickson, 2012). Its case study design aims to offer in-depth information about the difficulties encountered by the participants in relation to the aim and purpose of experiments. As Stake (1995) advocated, a case study is expected to catch the complexity of a single case.

The laboratory reports, the lesson plans and teaching materials that they had prepared to teach in the laboratory were collected. In addition, short interviews were conducted with many 
of them, while preparing lesson plans. The goal of the conducted interviews was to probe preservice teachers' understanding of the aim of each experiment and the purpose of experiments in physics teaching. Secondly, the goal was to explore the difficulties they encountered while planning a lesson and while preparing teaching materials. All interviews were audio-taped and transcribed for analysis. Examples of interview questions are shown in the Appendix.

The principal research investigator was also the instructor of the course. The role of the main researcher and the project assistants was made clear to the participants. The interviews were conducted with informed consent and by following the University Research Ethics Committee protocols. Attention was given to the research ethics (Gregory, 2003) and the associated issues (anonymity of participants and the role of the researcher).

\section{Data Analysis}

The collected lesson plans and laboratory reports were analyzed in terms of the aim of the experiments and the purposes for which experiments had been used. Qualitative analysis (Erickson, 2012) was conducted to identify common themes and particular trends within and among the participants. The coding was open-ended; the categories emerged from the data (Coffey \& Atkinson, 1996). The data were analyzed by comparing the responses for each question both across the interviewees and through each interviewee to identify key categories and features among pre-service teachers. We generated initial categories from interviews, lesson plans and lab reports of each participant. We constantly compared new data from the data sources with the current categories, and refined them. When clarification was needed, we collected more data by conducting focused conversations with the participants. The two (2) project assistants and the author (as the principal researcher) carried out the analysis with $91 \%$ inter-reliability. 


\section{Results}

In presenting the results, we refer to samples of lesson plans, quotes from the conducted interviews and excerpts from their laboratory reports. The results of the study are presented under the following three main sub-headings:

(1) Pre-service physics teachers' understandings of the aim of experiments,

(2) Pre-service physics teachers' understandings of the purpose of experiments and,

(3) Pre-service physics teachers' difficulties in preparing and planning to teach.

\section{Pre-service physics teachers' understandings of the aim of experiments}

The following categories have emerged from the participants' statements in the interviews, in their laboratory reports and lesson plans:

1a. In the first weeks in their lab reports they wrote that the aim is to verify or illustrate theory or a scientific law. The aim of the experiment is to understand and verify theory, i.e. "to verify Ohm's law" and, "to verify Hooke's law". And, "The aim is to determine the validity of Hooke's law for springs with different constants". Also, "The aim of the experiment is to confirm that as the length l of the pendulum increases, period will increase". The last sentence is a wrong statement in terms of theory. Sometimes, when they write the aim of the experiment, their difficulties with concepts are revealed. For example, the aim is: "To find out which material will save heat longer. I am going to verify Newton's cooling law ...". Eighty-two (82) teachers are allocated in this category during the first three weeks.

1b. The aim is to find out the relationship between the variables involved in the experiment: "The aim is to find out a mathematical relationship between the variables of force $(F)$ and the extension (x) of the spring". During the first three weeks, thirty-five (35) teachers are allocated in this category. 
1c. The participants demonstrated difficulties in understanding that the aim of experiments is to design a controlled experiment so that they determine or calculate some quantities (based on the collected measurements). It takes around six weeks for students to understand that the aim of an experiment is to design a controlled experiment in order to determine or calculate some quantities (based on the collected measurements). Thus, during the fourth to sixth week, only twenty-one students (out of 123) wrote in the first version of a lab report in the aim section: "The aim is to measure the acceleration due to gravity, by using a simple pendulum motion". And, "To measure the acceleration due to gravity by studying the simple pendulum motion and calculate the experimental error" (from the pendulum motion lab report). For Hooke's law experiment: “The aim of the experiment was to study Hooke's law and calculate the spring constant for each spring”. Only 6 (six) teachers belong to this category in the first three weeks.

Thus, in a similar vein, fifty (50) teachers during the seventh to ninth week wrote: "The experiment was carried out in order to investigate the rates of cooling of each insulating material and then, find out the best of the available insulating materials" (from the insulation lab report).

The following bar chart (Figure 1) shows the numbers of teachers with respect to their understanding of the aim of experiments in physics instruction during one semester.

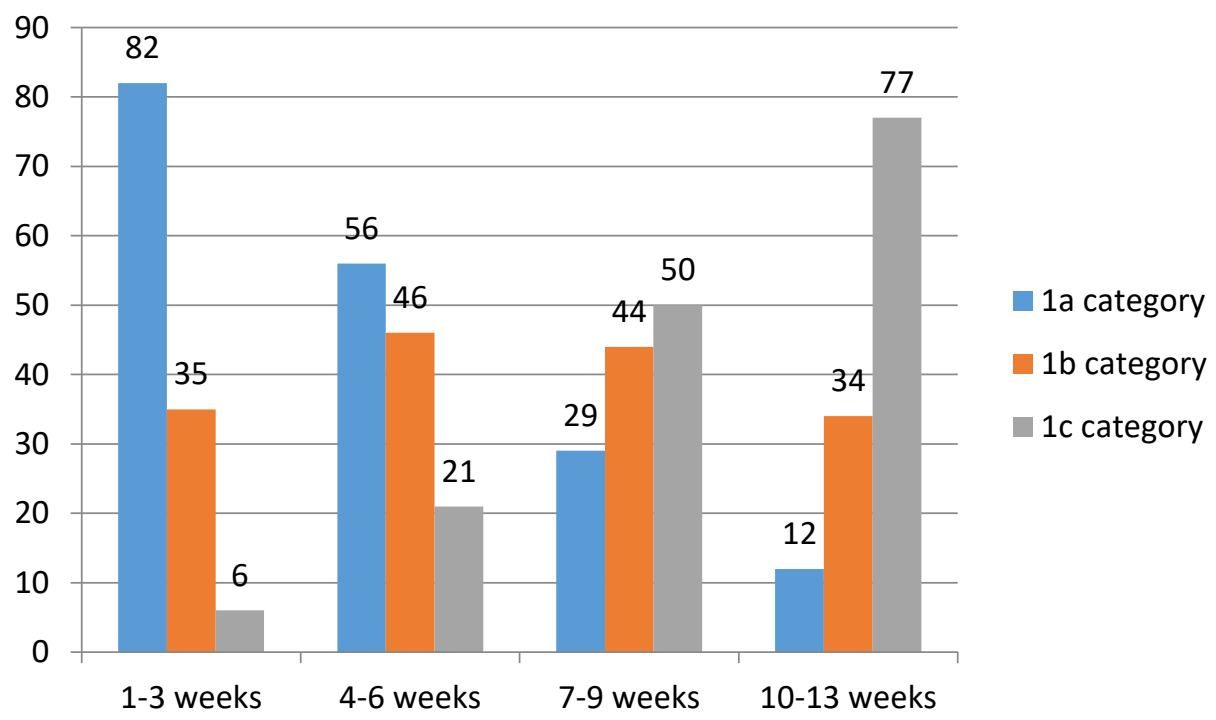

Necatibey Eğitim Fakültesi Elektronik Fen ve Matematik Eğitimi Dergisi 
Figure 1 The number of pre-service teachers with respect to their understanding of the aim of experiments during one academic semester (Total number of teachers $=123$ )

Furthermore, the above bar chart shows how teachers' understandings have 'shifted' from the idea that the aim is to "verify" or "confirm" theory to the idea that the aim is to calculate some quantities based on the collected measurements during one semester. Initially, there was a strong belief that the aim of the experiment was to verify a hypothesis or to confirm a relationship between variables. It took more than half of an academic semester (after the seventh week) for them to "move" to the idea that through experiments the aim is to calculate rates of cooling or determine some quantities. Thus, during the period of the tenth to the thirteenth week, seventy-seven (77) pre-service teachers successfully reported that the aim of an experiment is to calculate the constant of springs based on the collected measurements. The number of teachers allocated in the first category decreases from 82 to 56 (during the $4^{\text {th }}$ to $6^{\text {th }}$ week), then to 29 (during the $7^{\text {th }}$ to $9^{\text {th }}$ week) and around the end of the semester to 12 teachers. On the other hand, the number of teachers allocated in the third category increased from 6 to 21 , then to 50 , and during the final weeks to 77 teachers.

\section{Pre-service teachers' understandings of the purpose of experiments in physics teaching}

The following categories have emerged from the data:

2a. The purpose of teaching an experiment is to understand and verify theory. One student who taught accuracy, precision and experimental errors in the context of free fall experiment, wrote that the topic of the lesson was free fall. With the help of the instructor, he corrected himself saying that the topic of his lesson was about ideas of accuracy, precision and errors (systematic and random ones).

In the first three weeks, eighty (80) teachers (out of 123) wrote in their lesson plans that the purpose was to illustrate and verify theory, and thus, understand theory better. From the $4^{\text {th }}$ until $6^{\text {th }}$ week, this number is reduced to 51 (fifty-one) teachers. Later on, from $7^{\text {th }}$ to $9^{\text {th }}$ week, the teachers were reduced to twenty-nine (29). Finally, around the end of the course, only ten (10) teachers kept the idea that the role of experiments is to test theory.

$2 \mathrm{~b}$. The purpose is to find out the relationship between the variables involved in the experiment: In the first three weeks, thirty-three (33) teachers supported the idea that "the purpose of experiments is to find out the relationship between two variables".

2c. The purpose of the experiment is to develop laboratory skills and to teach specific laboratory skills. Pre-service teachers have experienced difficulties in understanding that the 
purpose of experiments is to develop laboratory skills (i.e. how to design a fair test, how to plot points, calculate the slope of a line graph, analyze data, interpret data and so on). Only ten (10) teachers in the first three weeks wrote in their lesson plans that the purpose was to develop certain laboratory skills. It takes five to six weeks for pre-service teachers to understand that the purpose is to develop experimental skills (i.e. to learn how to design an experiment, to plan an experiment by identifying variables and design a fair test, to plot points and the graph, to read the graph, learn how to interpret and use graphs in the analysis and explanation of results and so on). Specifically, during the $4^{\text {th }}$ to $6^{\text {th }}$ week, twenty-nine (29) students are allocated in this category. From $7^{\text {th }}$ to $9^{\text {th }}$ week, the number increased to fifty-three (53) students. Finally, during the last four weeks, eighty-one (81) students wrote that "the purpose of the insulation experiment was students to learn how to define variables, how to plan and perform a controlled experiment, to draw a best fit curve, determine which insulating material is the best".

The following bar chart (Figure 2) shows the numbers of teachers with respect to their understanding of the purpose of experiments in physics instruction during one semester.

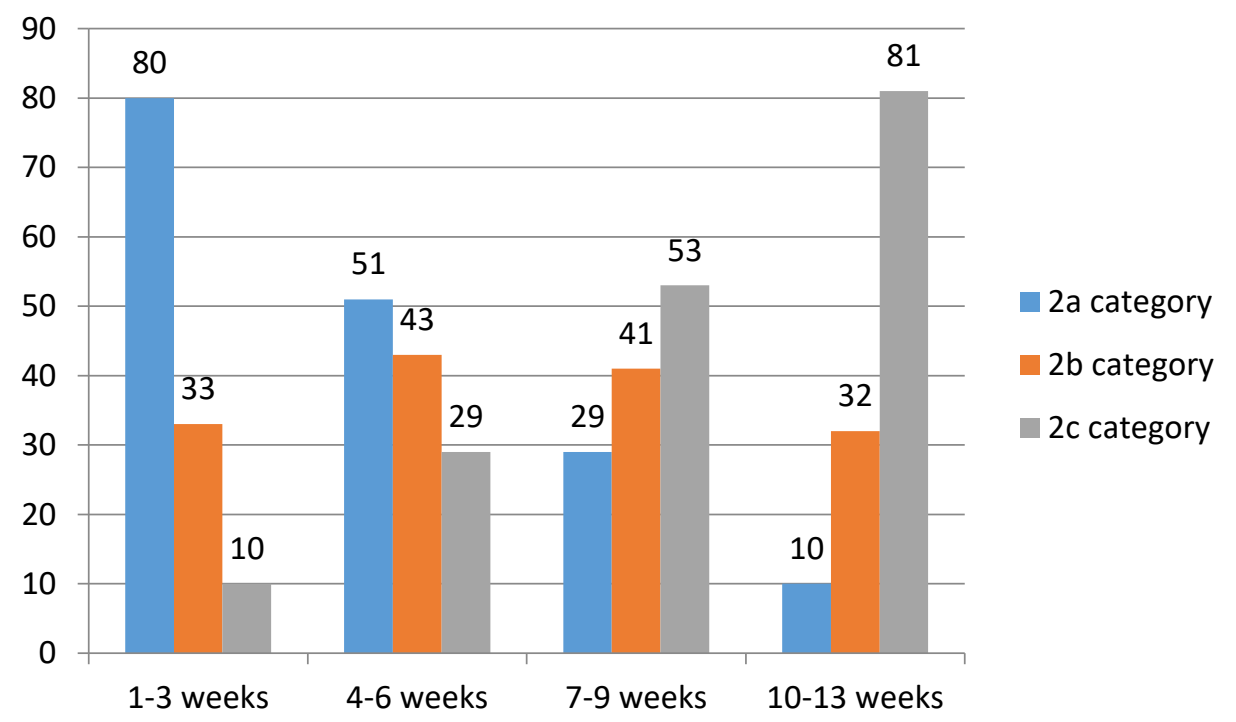

Figure 2 The number of pre-service teachers with respect to their understanding of the purpose of experiments during one academic semester (Total number of teachers $=123$ )

\section{Pre-service-teachers' difficulties in preparing lesson plans to teach}

Preparing to teach in the laboratory presents a great challenge. The difficulty to prepare a lesson plan with learning goals related to the development of particular experimental skills is clear. They are not confident to teach laboratory skills and their plans are weak.

Tasks, like the following (Task 1 and 2 in Figures 3 and 4, correspondingly), were distributed for classwork. Such tasks were developed in order to promote the idea that when 
teaching in the laboratory, teachers should use experiments to develop laboratory skills. The participants were asked to develop lesson plans and teaching materials.

Task 1. You, as a teacher

Prepare a lesson plan to teach your students how to plan (planning part), make a prediction and take measurements (obtaining evidence) in the insulation experiment.

Figure 3 Task 1 asking for a lesson plan about the prediction and obtaining evidence parts of the insulation experiment.

Task 2. You need to develop a lesson plan for a lesson about the experiment of insulation for Grade 12 for an advanced student's level. You may use and refer to your notes.

Figure 4 Task 2 asking for a lesson plan about the whole experiment of insulation

When working on Task 1, the participants have confused the context (theory) with the laboratory skills (planning, making prediction and decisions on how to take measurements) they would want to teach and develop in their secondary students. They have talked only about theory of insulation, heat and temperature, heat capacity and Newton's cooling law (as Figure 5 shows). They also sketched the graph of the cooling process of hot water. Similarly, they have written that "students will be able to identify and determine the difference between heat and temperature". And: "Students will learn what an insulator is" and, "Understand how insulators work". The lesson objectives are closely related to theory and physics concepts (heat, temperature, thermal equilibrium). Or, they say that the topic is about heat, temperature and insulation. On the whole, while they are asked to prepare a lesson plan to teach the planning and making prediction for the insulation experiment, their focus was not on the particular lab skills but on how to teach the insulation theory. The following is representative of such tendency among the participants.

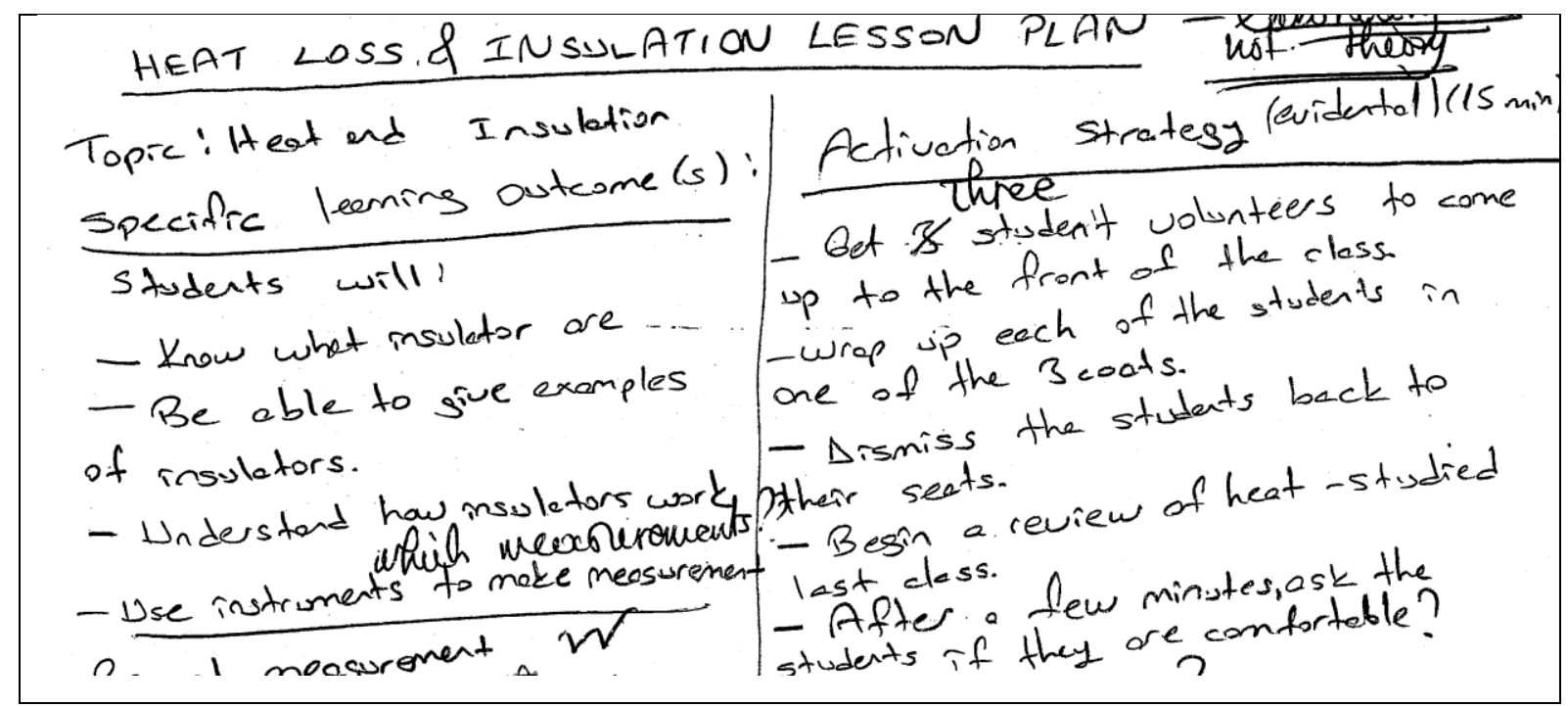

Figure 5 Excerpt from a lesson plan for the insulation experiment 
They also talked about how to develop an introductory lesson before the experiment in the laboratory. When they talked about the introductory lesson, they restricted themselves around preparation for teaching conceptual knowledge, without referring to the process and laboratory skills necessary to perform the experiment. Or, it has happened that in their lesson plans when they need to write what the teacher and the students will do (teaching methods and strategies) in the classroom, they describe the different parts of an experiment. Instead, we wanted them to talk about the preliminary experiment and the class discussion, in which, students in groups or with the instructor talk about planning, variables and the planning of a controlled experiment.

Similarly, when working on Ohm's law experiment (in a similar task like Task 1 and 2), they thought that the lesson is about Ohm's law and theory. Thus, they wrote that the topic was about Ohm's law (not about the teaching of some experimental skills). And the lesson objective was: "By the end of the lesson, students will have understood the relationship between voltage and current and the related Ohm's law". As they explained in the interviews, in the usual undergraduate physics lab classes, they were given detailed instructions. Such laboratory courses did not leave much room for a deeper understanding and for taking initiatives.

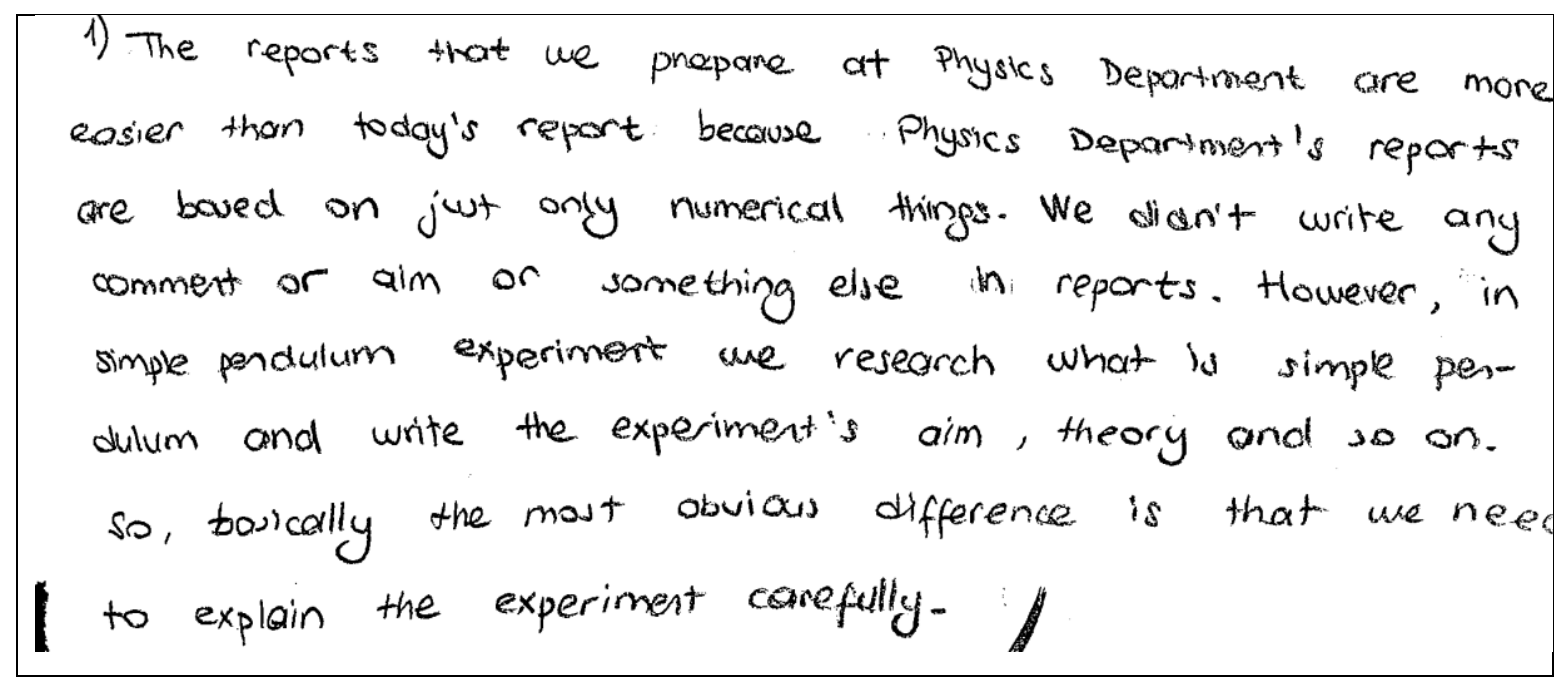

Figure 6 Quote from an interview

However, twenty-four (24) (out of 123) teachers answered that they will teach the theory of the experiment (Newton's cooling law) in the introductory lesson. They also said that they were going to review each part of the experiment and the lab report. "Use instruments to make measurements of temperature". "Carry out a controlled experiment". The following Figure 
(Figure 7) shows a part of a lesson plan in which the teacher successfully focused on laboratory skills.

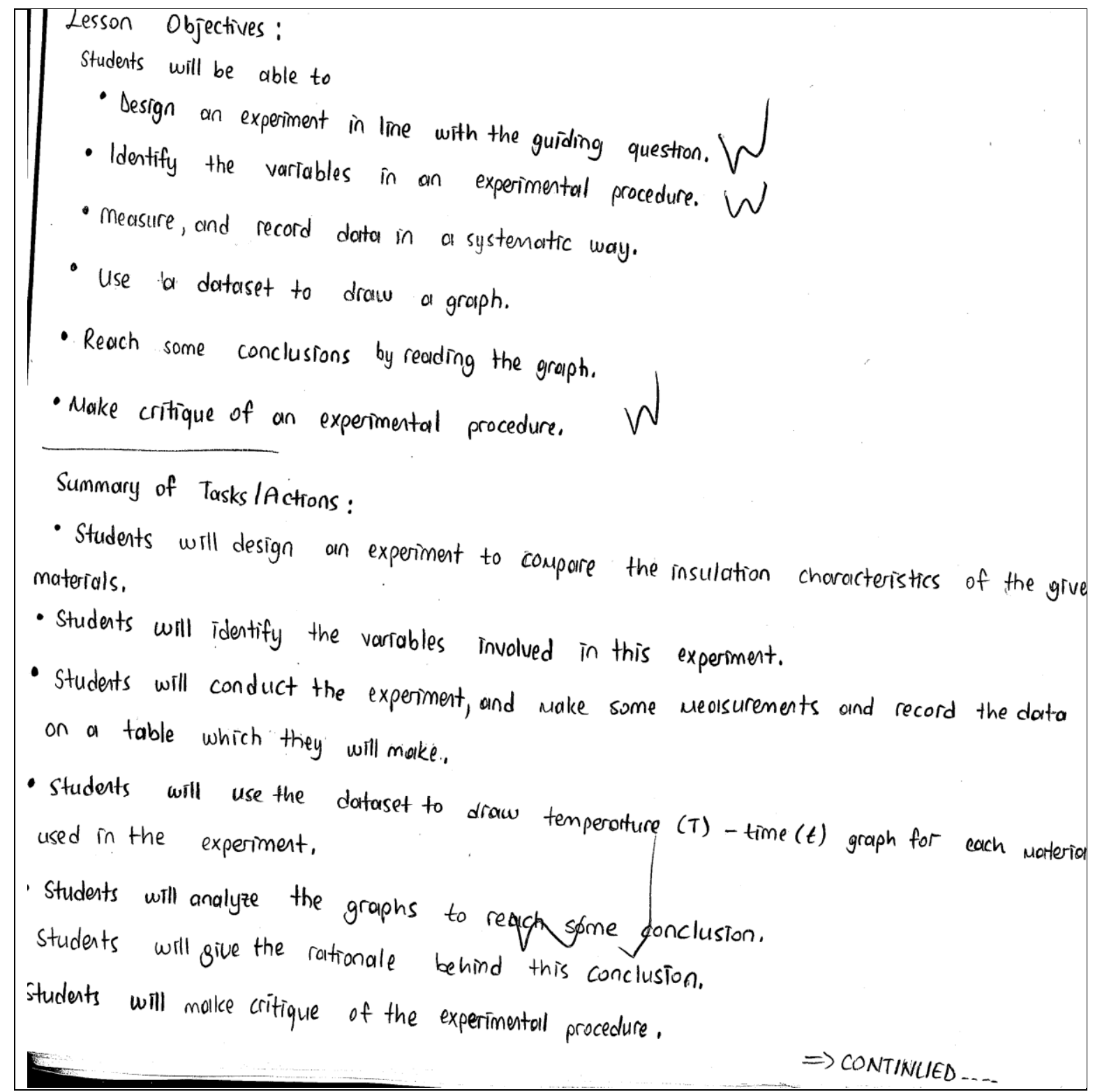

Figure 7 Part from a lesson plan focusing on the teaching and development of laboratory skills

In addition, Figure 8 shows a part of a lesson plan, in which pre-service teachers have demonstrated a good knowledge of learning objectives closely related to laboratory skills. 


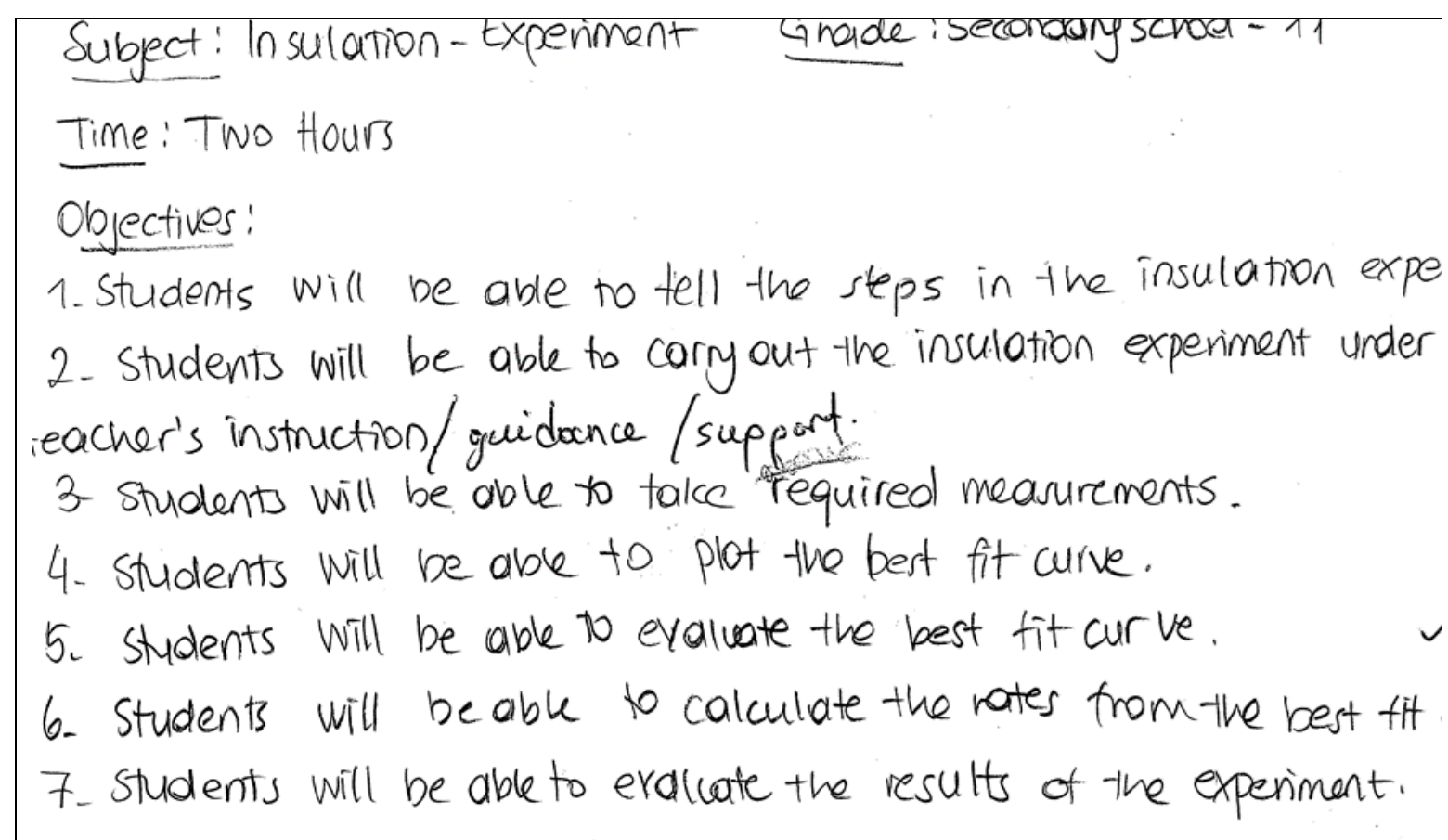

Figure 8 Excerpt from a lesson plan with lesson objectives related to the development of laboratory skills

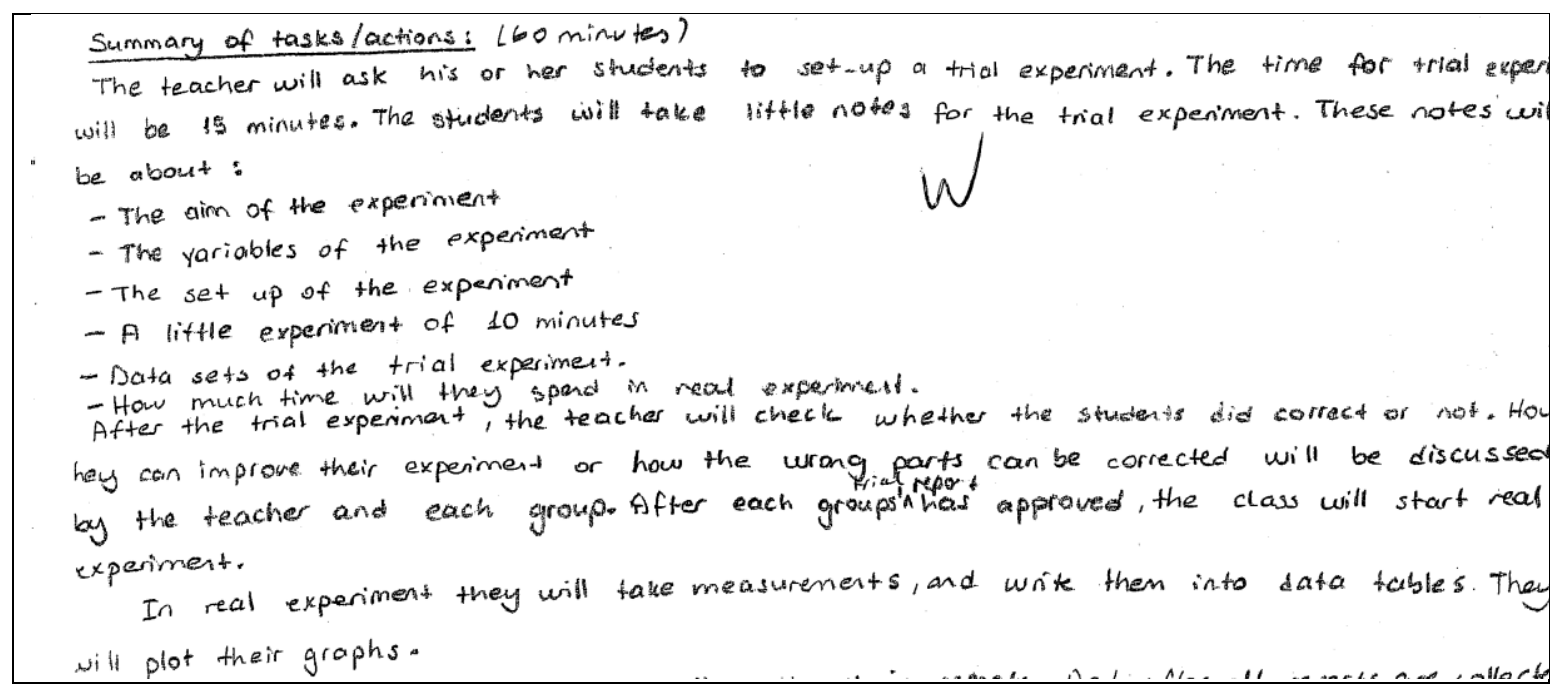

Figure 9 Lesson plan for a trial experiment and the experiment of insulation

Students experienced difficulties in writing learning objectives and teaching goals related to the development of laboratory skills. Their difficulties are due to the fact that in all physics education classes, they have had training and practice in developing lessons plans to teach only concepts of physics (theory).

Through practice and by time, they were able to articulate and write the following learning objectives:

- Teach to judge the range of measurements they need to take, when and why these need to be repeated, and how to deal with anomalous results. 
- Students will be able to draw a best fit line or best fit curve.

- Teach students to examine evidence for validity and reliability by considering questions of accuracy, error and discrepancy.

- Teach how to write the laboratory report.

- How to design a 'fair test'.

- How to collect and record data.

- How to analyze data.

- How to make a detailed analysis of results by using the plotted graph and make the calculation of slopes.

- In the preliminary experiment, they will make decisions about how to take measurements.

- Students to be able to plan the insulation experiment, to design a controlled experiment, to identify the variables involved and to carry out the preliminary experiment.

Figure 10 Learning Objectives closely related to the development of laboratory skills

One senior student with considerable teaching experience in internship schools explained in an interview: "Planning a lesson was difficult for me. I needed some guidance to design and plan my lesson. I keep the theory simple, so that I teach them laboratory skills. I learned about progression in teaching”.

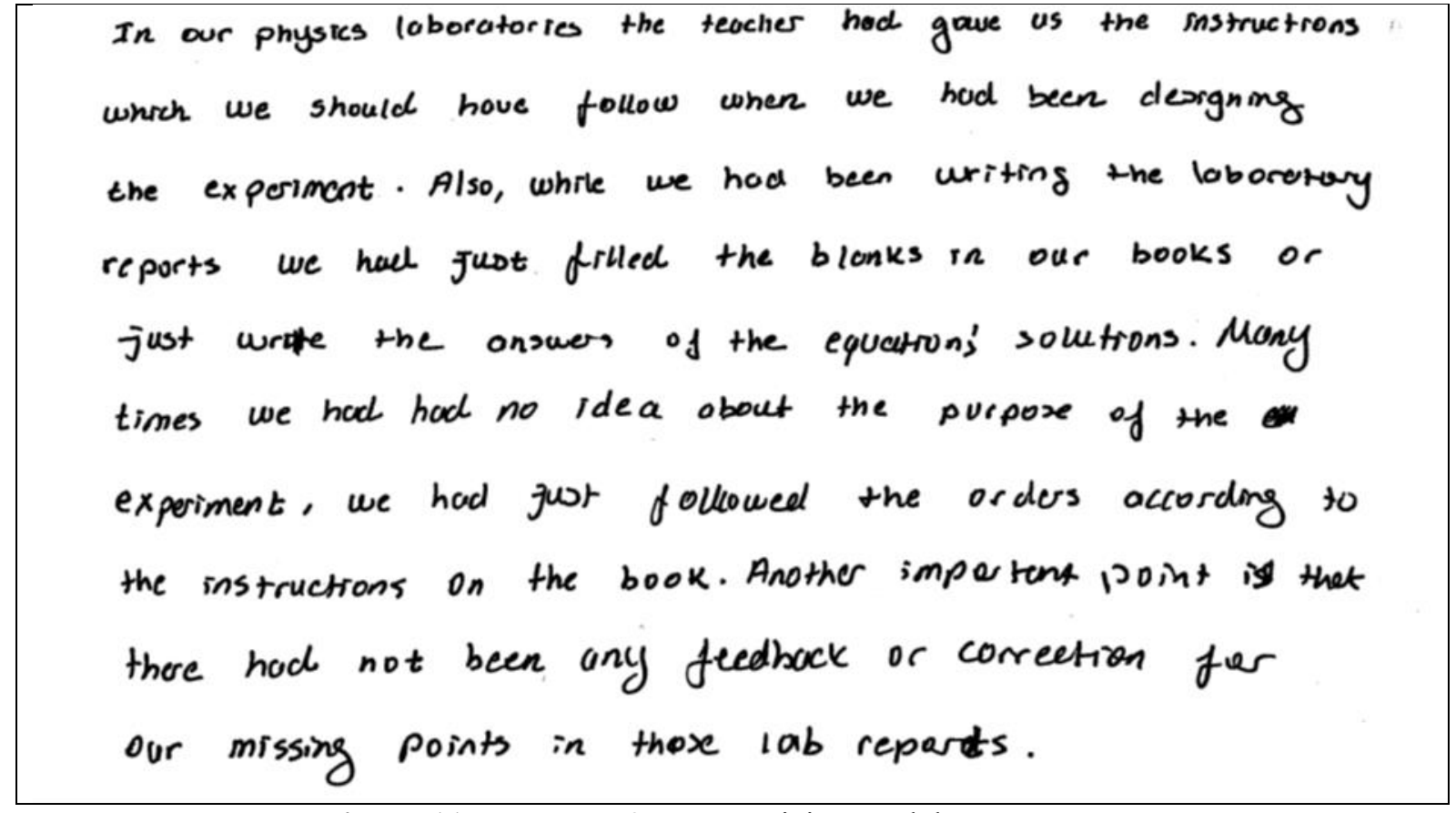

Figure 11 One quote from a participant's laboratory report

On the other hand, a few of them had prepared adequate lesson plans. They had also prepared stimulating questions to initiate thinking and discussion in the class. They were confident to teach about what is included in the analysis and explanation of results and how to teach the relevant sections. 
Quite many teachers asked for more guidance and clear guidelines on how to proceed as teachers when planning for teaching and when preparing teaching materials.

\section{Discussion of Results}

The study investigated pre-service teachers' understandings of the aim of experiments, understandings of the purpose of experiments and, their difficulties when preparing and planning to teach. We have adopted the position that practical work should help students develop a broad array of laboratory skills; that is, students should be able to plan experiments, graph data, analyze data, describe the relationship between the variables and much more. The study confirmed results from previous studies, but also has elicited new findings.

Initially, there was a strong belief that the aim of experiments was to "verify" or "confirm" theory. Students viewed the aim of lab as to prove theory and demonstrate concepts. Teachers' understandings have "shifted' from the idea that the aim is to "verify" or "confirm" theory to the idea that the aim is to calculate some quantities based on the collected measurements during one semester. Initially, there was a strong belief that the aim of the experiment was to verify a hypothesis or to confirm a relationship between variables. It took more than half of an academic semester (after the seventh week) for them to "move" to the idea that through experiments the aim is to calculate rates of cooling or determine some quantities. Thus, during the period of the tenth to the thirteenth week, seventy-seven (77) pre-service teachers successfully reported that the aim of an experiment is to calculate the constant of springs based on the collected measurements.

Similarly, only a few of them mentioned the development of laboratory skills as a purpose in the first three weeks. Unfortunately, the main goal of the laboratory, to teach and develop skills like the analysis of data, interpretation and evaluation skills was mentioned by relatively few pre-service teachers.

Indeed, at the beginning of the course, the goal of the development of laboratory skills was totally new for the participant teachers. There was a latent assumption of the participants that students learn physics by demonstrating or applying ideas in the school laboratory that were taught earlier in class. Such a view is naïve, as discussed in the literature review section. However, when pre-service teachers enter a laboratory or a classroom with certain expectations, it is difficult to change them. As mentioned in the literature (Hu et al., 2017), many students and some teachers consciously or subconsciously maintain the assumption that experiments and laboratory activities promote conceptual understanding. 
Secondly, when performing experiments in the physics laboratory classes, in the Physics Department, they are always provided with guidelines and instructions on what to do and how to proceed. They need to follow such guidelines and not to make their own decisions. Following the instructions or getting the "right" data set or answer is seen as the purpose of the experiment.

The program was successful in helping the participants to gradually "shift" from the idea that experiments are used to verify a hypothesis or confirm theory to the idea that it is the development of laboratory skills, which is the purpose of using experiments.

Students experienced difficulties in writing learning objectives and teaching goals related to the development of lab skills. At the beginning, the participants wrote learning objectives related to the teaching of theory and not to the development of experimental skills. This is mainly because in all physics education classes, they have had training and practice in developing lessons plans to teach only concepts of physics (theory).

Such results are consistent with results presented by the study carried out by Schauble and her research team (1995) which revealed a discrepancy between students' and teachers' understanding of the purposes of experiments and the related reasoning. Also, Hu et al., (2017) found that introductory undergraduate students viewed experiments as supplemental tools for conceptual learning. In contrast, higher-level students believe that experiments provide opportunities to emphasize the development of laboratory and scientific skills. The introductory students would emphasize that experiments are used to test theory.

During the period of one academic semester, asking students to explain what they were doing (during the class and interviews) helped them improve their understanding of the purpose of experiments focused on the development of laboratory skills.

The issue, then, is how best to promote the idea in pre-service teachers that through experiments we want to develop laboratory skills in students. For the lab to reach its full potential, physics teachers should carefully match practical activities to the different objectives of the school science curriculum and various laboratory skills. The same experiment may be used for different purposes. For example, the free fall experiment may be used to teach them how to design a controlled experiment or how to plot data and how to analyze them. The implication, therefore, is that a key task for teachers is to communicate effectively to students what the teaching goals of an experiment are; to differentiate between the "aim" of answering the question being investigated and the "purpose" of the experiment, which is related to the teaching goals of the activity. 
Also, the participants created new teaching materials and tasks and developed teaching methods for the lab. Such teaching plans and written materials is a source of information about the changes in teachers' use understanding of the purpose of each experiment and the changes they underwent during the course.

The participants need to gain more confidence in preparing lesson plans to teach in the laboratory. More lesson plans and tasks are needed. Pre-service teachers need to develop a commitment to continue learning to teach.

The reviews by Lazarovitz and Tamir (1994) and Lunetta and Hofstein (1982; 2004) reported a mismatch between the goals articulated for the school science laboratory and what students regularly do in these activities. Teachers should make conscious decisions about what laboratory skills they want to develop with particular lab activities and accordingly, communicate such lab skills to students and then plan for appropriate tasks. Thus, we want to recommend consistency between goals and practices in the teaching and learning in the school laboratory.

The teacher should be able to make a professional decision and select a few learning objectives related to certain laboratory skills and think how they will fit in a teaching unit. On the other hand, if the teacher wants to achieve many purposes through experiments, this may result to a failure. As Séré (2002) advocated, each specific laboratory activity should have only a few and specific teaching goals and lab skills to address. To foster and support the development of laboratory skills, it is necessary to carefully select learning objectives and then, a careful planning for teaching in the laboratory. We want to take this point of view further to argue that the teacher should communicate the specific learning objectives to students. In the laboratory, students should be encouraged to reflect on data, analyze the data and explain it by using theory, as well as consider anomalous data, uncertainty and sources of errors. They, then, need to communicate and make explicit their purpose to their students. Furthermore, teachers should decide on the lab skills rather than the content knowledge. Towards such direction, teachers should make strong links between the purpose, the development of specific laboratory skills and the experiment that they perform each time. 


\section{Limitations of the study}

The current study has two limitations. One limitation has to do with the participants themselves. They were not selected randomly since they had enrolled in a laboratory course for pre-service teachers in a Physics Teaching Department. Secondly, more time is necessary for pre-service teachers to develop better understanding that, through experiments, the goal is to develop laboratory skills. In addition, it would be better to follow the participants during their teaching in the first years of teaching in schools.

\section{Implications for pre-service physics teacher education}

This study raises important questions for physics teacher educators. Physics educators may take for granted that pre-service teachers know how to develop lesson plans which aim to promote the development of laboratory skills. However, this study with more studies carried out in Europe and the US have provided evidence that students and teachers may believe that experiments are used in physics instruction to test or verify theory. Trainee teachers experience difficulties and have needs which must be considered in planning and implementing their initial education. In pre-service teacher education, instruction should explicitly address the underlying understandings of the participants with regard to the aim and the purpose of experiments in physics instruction.

Pre-service teacher education programs should put more emphasis on the role of laboratory work in physics education. The laboratory skills are crucial.

These research findings offer strong support for the need of the development of courses for the preparation of physics teachers. Pre-service physics students need more opportunities to learn about and practice teaching lab skills. There should be courses so that preservice teachers have more opportunities to develop lesson plans and teaching materials to use them when teaching in the lab. Like Hofstein and Lunetta (2004), we believe that: "The literature has suggested that inconsistencies between teachers' goals and behaviours and limitations in teachers' skills, in this case in the school laboratory, should be addressed carefully in long-term professional development programs designed to develop the understanding, knowledge and skill of professional teachers" (Hofstein \& Lunetta, 2004, p. 45). The research presented gave much importance to the importance of teacher preparation because we believe in the important role of the teacher in the laboratory. This is line with many studies in teacher preparation, in general and in physics teacher preparation, more specifically. For example, Sharma and 
Ahluwalia (2018) argued in favour of the crucial role of the physics teacher even in online or virtual advanced physics laboratories.

\section{Implications for curriculum development}

We need to give more importance to laboratory work in the Turkish physics curriculum. This means that less theory will be taught so that there will be time for experiments. This is what European countries do. However, one of the main issues is how to develop and organize lab courses to achieve their goals. As Holmes and her team (2017) argued, one of the most important areas for curriculum development is how to provide educationally effective experimentation experiences to introductory physics students.

This study may contribute to those who wish to design a laboratory course for physics pre-service teachers. Curriculum developers should be aware of the difficulties students have with understandings of the purpose of experiments in physics teaching and their difficulties with adequate planning. We need not only to revise the course but also to develop one researchbased module or more for initial teacher education of physics teachers. Pre-service physics teachers need to be taught about teaching methods specific to the laboratory and about development of laboratory skills. This study should inform a new course and vice versa; students' achievement and teachers' experience should inform new research. In line with suggestions by Khaparde (2019), we want to underline that research universities and departments responsible for pre-service physics teacher education need to adopt approaches emerging from research in order to support the quality of laboratory courses.

\section{Acknowledgement}

This study is a part of a research project entitled: "Pre-paring pre-service physics teachers to teach and assess scientific evidence in the shool physics laboratory". The project was conducted by the author and was funded by the Bogazici University Research Office (BAP) with the project number BAP 10800. I am grateful to all the preservice teachers who participated in the study. In addition, many thanks go to my student Mehmet Akif Çolak who helped me with the preparation of the manuscript. 


\section{References}

Abrahams, I. \& Millar, R. (2008). Does practical work really work? A study of the effectiveness of practical work as a teaching and learning method in school science. International Journal of Science Education, 30, 1945-1969. doi:10.1080/09500690701749305.

Abrahams, I. \& Millar, R. (2009). Practical work? Making it more effective. School Science Review, 91(334), 59-64.

American Association of Physics Teachers (1997). Goals of the Introductory Physics Laboratory. The Physics Teacher, 36 (12), 546-548.

American Association of Physics Teachers (2014). AAPT Recommendations for the Undergraduate Physics Laboratory Curriculum. College Park, MD: American Association of Physics Teachers.

Bozzo, G. (2020). "Free-Fall Demonstrations" in the High School Laboratory. The Physics Teacher, 58 (1), 23-27. 2020. doi: 10.1119/1.5141966.

Coffey, A. \& Atkinson, P. (1996). Making sense of qualitative data. London: Sage.

Erickson, F. (2012). Qualitative research methods for science education. In B. J. Fraser, K.G. Tobin and C. J. McRobbie (Eds.) Second International Handbook of Science Education (pp 1451-1469). Dordrecht, Netherlands: Springer.

Etkina, E., Van Heuvelen, A., Brookes, D. T. \& Mills, D. (2002). Role of Experiments in Physics Instruction - A Process Approach. The Physics Teacher, 40, 351 - 355. doi: $10.1119 / 1.1511592$.

Gkioka, O. (2019). Preparing pre-service secondary physics teachers to teach in the physics laboratory: Results from a three-year research project. AIP Conference Proceedings 2075, 180009 (2019). doi: 10.1063/1.5091406.

Gregory, I. (2003). Ethics in Research. London: Continuum.

Gunstone, R.F. (1991). Reconstructing theory from practical experience. In B. Woolnough (Ed.) Practical Science (pp 67-77). Milton Keynes: Open University Press.

Gunstone, R.F. \& Champagne, A.B. (1990). Promoting conceptual change in the laboratory. In E. Hegarty-Hazel (Ed.) The student laboratory and the science curriculum (pp 159-182). London: Routledge.

Hart, C., Mulhall, P., Berry, P., Loughran, J. \& Gunstone, R. (2000). What is the purpose of this experiment? Or can students learn something from doing experiments? Journal of Research in Science Teaching, 37(7), 655-677. https://doi.org/10.1002/1098-2736(200009)37:7<655::AIDTEA3>3.0.CO;2-E.

Hegarty-Hazel, E. (1990). The student laboratory and the science curriculum: An overview. In E. Hegarty-Hazel (Ed.) The student laboratory and the science curriculum (pp. 3-26). London: Routledge.

Hodson, D. (1993). Rethinking old ways: Towards a more critical approach to practical work in science. Studies in Science Education, 22, 85-142. http://dx.doi.org/10.1080/03057269308560022

Hofstein, A. \& Lunetta, V.N. (1982). The role of the laboratory in science teaching: Neglected aspects of research. Review of Educational Research, 52, 201-217. https://doi.org/10.2307/1170311.

Hofstein, A. \& Lunetta, V. N. (2004). The laboratory in science education: Foundations for the twenty-first century. Science Education, 88(1), 28-54. doi: 10.1002/sce.10106. 
Holmes, N., Olsen, J., Thomas, J. L. \& Wieman, C. E. (2017). Value added or misattributed? A multi-institutional study on the educational benefit of labs for reinforcing physics content. Physical Review Physics Education Research, 13, 010129. doi: https://doi.org/10.1103/PhysRevPhysEducRes.13.010129.

Hu, D., Zwickl, B. M., Wilcox, B. R. \& Lewandowski, H. J. (2017). Qualitative investigation of students' views about experimental physics. Physical Review Physics Education Research, 13, 020134. doi: https://doi.org/10.1103/PhysRevPhysEducRes.13.020134.

Khaparde, R. (2019). Experimental roblem solving: a plausible approach for conventional laboratory courses. IOP Conf. Series: Journal of Physics: Conf. Series 1286 (2019) 012031. doi:10.1088/1742-6596/1286/1/012031.

Lazarowitz, R. \& Tamir, P. (1994). Research on using laboratory instruction in science. In D. L. Gabel (Ed.) Handbook of Research on Science Teaching and Learning (pp. 189-130). New York, NY: MacMillan.

Lunetta, V. N., Hofstein, A. \& Clough, (2007). Learning and teaching in the school science laboratory: An analysis of research, theory and practice. In S. K. Abell and N. G. Lederman (Eds.) Handbook of Research on Science Education (pp. 393-441). Mahwah, NJ: Lawrence Erlbaum Associates.

Schauble, L., Glaser, R., Duschl, R. A., Schulze, S. \& John, J. (1995). Students' understanding of the objectives and procedures of experimentation in the science classroom. Journal of the Learning Sciences, 4(2), 131-166. https://doi.org/10.1207/s15327809j1s0402_1.

Séré, M-G. (2002). Towards renewed research questions from outcomes of the European project labwork in science education. Science Education, 86, 624-644. https://doi.org/10.1002/sce.10040.

Sharma, S. \& Ahluwalia, P. K. (2018). Can virtual labs become a new normal? A case study of Millikan's oil drop experiment. European Journal of Physics, 1-18. https://doi.org/10.1088/1361-6404/aada39.

Stake, R. E. (1995). The art of case study research. London: Sage Publications.

Talim Terbiye Kurulu Başkanlığı - Board of Education. (2018). Ortaögretim Fizik Dersi (9, 10, 11 ve 12. Sinfflar) Öğretim Programı. Ankara: MEB.

Tamir, P. (1991). Practical work in school science: an analysis of current practice. In B. Woolnough (Ed.) Practical Science: The Role and Reality of Practical Work in School Science (pp 13-20). Milton Keynes: Open University Press.

Tobin, K. (1990). Research on science laboratory activities: In pursuit of better questions and answers to improve learning. School Science and Mathematics, 90, 403-418. https://doi.org/10.1111/j.1949-8594.1990.tb17229.

Trumper, R. (2002). What do we expect from students' physics laboratory experiments? Journal of Science Education and Technology, 11, 221-228. doi: 10.1023/A:1016016417872.

Wilcox, B. R. \& Lewandowski, H. J. (2017). Developing skills versus reinforcing concepts in physics labs: Insight from a survey of students' beliefs about experimental physics. Physical Review Physics Education Research, 13, 010108. doi: https://doi.org/10.1103/PhysRevPhysEducRes.13.010108. 


\section{Appendix}

\section{Interview Questions:}

Tell me how you develop your lesson plans for teaching in the laboratory.

How do you teach experiments in the laboratory?

What is the main focus of this experiment?

What lab skills will you teach in this experiment?

What is the purpose of using this experiment in your teaching? (Or, why are you using this experiment in your teaching?)

Do you let your students know what laboratory skills they will develop?

You, as a trainee physics teacher, what kind of help and support you need in your pre-service education so that you teach experiments with confidence? 